\title{
The Urban Planning and its Evolution in Spain
}

\author{
José Romero Postiguillo* \\ General Coordinator of Works, Infrastructures, Public Services and Evironment of the Toledo City Council, Spain
}

*Corresponding author: José Romero Postiguillo, General Coordinator of Works, Infrastructures, Public Services and Environment of the Toledo City Council, Spain.
Received Date: May 10, 2020

Published Date: May 29, 2020

\begin{abstract}
Since the first written vestiges of city planning, referred in the American Laws of the Indies , until the orderly growth of cities was promoted after the industrial revolution, the legislator has tried to harmonize the development of cities with different criteria, from the initial ones based on health, to the current ones with environmental and sustainability standards.
\end{abstract}

Keywords: Urban planning; Town planning; Spanish urban planning legislation

\section{Aim of this Paper}

This research paper aims to list the Spanish legislation in relation to urban planning in order to indicate the different legislation in force at this time in order to, from here, and in other articles, analyze the administrative procedure of territorial planning and the consequences that could be derived from the annulment of municipal planning, that is, its administrative, social and economic impact.

\section{Introduction}

We could affirm that urbanism, as the seed of what we know today, was born from the industrial revolution. From then on, the economy stops relying on agriculture and crafts to become dependent on industry. Thus, the city ceases to be the meeting point for the exchange and sale of merchandise, to be the focus of daily activity, a place where production factories are installed. This consequently leads to a change in the location of the population, which ceases to be dispersed, formerly located in the countryside, to now concentrate on the "new" cities.

One of the clearest examples of transformation after the industrial revolution is seen in the city of London: in 1800 it had a million inhabitants, in 1851 two million, and in 1881 four million. The main consequence arising from this rapid growth in such a limited area is, fundamentally, the structural and functional disorganization of the elements that make up the city and its services as a result of rapid growth, which leads to a tremendous disorganization in development and in daily sustainability.

Modern urban planning, now conceived in a global and collaborative way, is understood as comprehensive planning, that is, as a set of instruments to order and define land uses, which specifies the urban regime of land ownership and regulates the urban administrative activity. Within urban planning as a whole, we find various disciplines that carry out its activity: planning, management and discipline, as well as intervention in the land market; all of them tools regulated and ruled through Urban Law [1-4].

\section{The Evolution of Modern Spanish Legislation in} Urban Planning

- $\quad$ The first Municipal Ordinance of Madrid appeared in relation to the Urban and Rural Police, approved by the Superior Chief of the province on November 16, 1847.

- Municipal Ordinances of Barcelona, approved by agreement of the City Council of November 11, 1856.

- $\quad$ Royal Order of July 25, 1846 of the Minister of Governance Pidal, with which the obligation is established to raise the geometric plan of the population, its outskirts and walks, tracing 
them according to their current state, on scale 1: 1.1250, and that the alterations that must be made for the future alignment of each street, squares, etc.

- Population Expansion Law of June 29, 1864: to try to give legal basis to the urban plans of the extensions of Madrid and Barcelona.

- Regulation for the execution of the Expansion Law (R.D. of April 25, 1867).

- Law of March 18, 1895 on sanitation and internal reform of large populations: which, as a mere fact of interest, reforms the Law of Forced Expropriation of January 10, 1879.

- $\quad$ The General Health Instruction approved by R.D. January 12,1904

- $\quad$ Creation of the Central and Provincial Commissions of Local Health (R.D. of May 11, 1920).

- Royal Order of August 9, 1923 approves hygienic conditions of the houses and the technical-sanitary conditions for the expansion and interior reform of the towns.

- The Municipal and Provincial Statutes of Calvo Sotelo of 1924 and 1925, which attribute competence in urban planning matters to the City Councils.

- $\quad$ Regulation of Works, Services and Municipal Assets of July 14,1924 . In which article 8 consecrates the zoning technique already introduced by the Technical-Sanitary Instructions of 1923.

- Regulation on uncomfortable, unhealthy and dangerous establishments of November 17, 1925.

- Law of May 12, 1956 on Land Regime and Urban Planning.

- The Law of May 12, 1956 was developed through the Regulation of Forced Construction and Municipal Land Registry (Decree 635/1964) and the Regulation of Reparcelling (Decree 1006/1966).

- Law 19/1975, of May 2, on the reform of the Law on Land Regime and Urban Planning.

- Law 8/1990, of July 25, on the reform of the Urban Planning and Land Valuations.

- By Royal Legislative Decree $1 / 1992$, of June 26 , the Consolidated Text of Law 8/1990 and the previous urban planning legislation was approved, and by Royal Decree 304/1993, of February 26, the table of validities of the Regulations of 1978.
- $\quad$ Royal Decree-Law 5/1996, of June 7, and Law 7/1997, of April 14, on liberalizing measures in the field of land.

On April 25, 1997, the Constitutional Court Judgment 61/1997, dated March 20, was published in the BOE, partially estimating the appeals against the Consolidated Text of 1992, declaring unconstitutional a large number of precepts for having been dictated by the State without having legislative competence for it.

- $\quad$ Law 6/1998, of April 13, on Land Regime and Valuations.

- Royal Decree-Law 4/2000 on Urgent Liberalization Measures in the Real Estate and Transportation Sector.

- Law 10/2003 on Urgent Liberalization Measures in the Real Estate and Transportation Sector.

- $\quad$ Law 8/2007, of May 28, on Land.

- $\quad$ Royal Legislative Decree 2/2008, of June 20, which approves the Consolidated Text of the Land Law.

- $\quad$ Royal Legislative Decree $7 / 2015$, of October 30, which approves the consolidated text of the Law on Land and Urban Rehabilitation of 2015.

That said, regardless of the regulatory powers of the State in terms of land referenced so far, the Spanish Constitution considers land use and urban planning as a competence of the autonomous communities, so all of them incorporate into their statutes of autonomy said legislative powers, the local entities maintaining the managerial powers, except the competition in the property regime.

\section{Acknowledgment}

None.

\section{Conflict of Interest}

No conflict of interest.

\section{References}

1. Moya AM (2001) Posada Herrera and the origins of Spanish administrative law: I Administration History Seminar. National Institute of Public Administration (INAP), pp. 169-184.

2. Terán FD (1999) History of urban planning in Spain. Cátedra Vol.3, pp. 400.

3. Llardent LRA (2015) La evolución conceptual del planeamiento y la legislación urbanística actual. Cuadernos de Investigación Urbanística, pp. 100.

4. Fernández Montalvo R (2007) Legislación urbanística estatal y autonómica. Principios e instituciones comunes. 